\title{
A technological platform using serious game for children with Autism Spectrum Disorder (ASD) in Peru
}

\author{
Vanessa Bonifaz Pedreschi ${ }^{1}$, Diego André Ospina Díaz ${ }^{2}$ Jimmy Armas Aguirre ${ }^{3}$, Paola A. Gonzalez ${ }^{4}$ \\ ${ }^{1}$ Universidad Peruana de Ciencias Aplicadas (UPC), Perú, u201410152@upc.edu.pe \\ ${ }^{2}$ Universidad Peruana de Ciencias Aplicadas (UPC), Perú, u201312293@upc.edu.pe \\ ${ }^{3}$ Universidad Peruana de Ciencias Aplicadas (UPC), Perú, jimmy.armas@upc.pe \\ ${ }^{4}$ Dalhousie University, Canada, paola.gonzalez@dal.ca
}

\begin{abstract}
Children with high-functioning ASD struggle with recognizing and expressing their emotions. Serious games, computerized intervention programs, have successfully been used in the treatment of this disorder. In this paper, we proposed an enhanced and comprehensive technological platform using serious games to optimize the process of emotional and social learning therapy in treating children with ASD. This platform consists of four phases: Patient Registration, Data Transmission, Reporting, and Analysis. The platform was validated and tested in an educational and behavioral therapy institute in Peru. 20 children between ages 3 to 10 years old participated in the study. Children were tested before and after using the SG. The preliminary results showed a significant improvement in emotion recognition after using the SG. The therapists also reported their satisfaction with the reporting aspect of the platform.
\end{abstract}

Keywords-- technological platform, serious games, behavioral therapy, autism, ASD.

\section{INTRODUCTION}

Autism Spectrum Disorders (ASD) are a group of conditions characterized by some degree of impairment of social behaviour, communication, and language, and by a restricted, stereotyped and repetitive repertoire of interests and activities [1]. ASD is diagnosed during the first three years of life and is more frequently found in men than women. According to the Institute of National Statistics and Informatics in Peru, it is estimated that $5.2 \%$ of the total national population suffers from disability, of whom approximately 10,223 people have Autism Spectrum Disorder (ASD) [2].

Recent technological and informatics developments have been applied to the diagnosis and treatment of ASD with successful results [3]. In addition to reducing costs, these technology applications have helped therapists develop tailored and focused applications that can deliver the stimuli according to the treatment plan [4].

Digital Object Identifier (DOI):

http://dx.doi.org/10.18687/LACCEI2019.1.1.278

ISBN: 978-0-9993443-6-1 ISSN: 2414-6390
Serious games (SG) are computer application programs developed to improve various cognitive, social and communication skills in people with ASD [5]. Particularly, these games are designed to foster learning of these skills in a more ludic, engaged, predictable and soothing environment [6]. Some of the key design aspects of these games to promote an active participation and systematic learning include: being immersed in storylines, having goals directed around targeted skills, having rewards and feedback about goal progress, increasing levels of difficulty, individualized training, and the offering of choice [7].

In this paper we evaluate and compare the technological platforms that have recently been used in the context of serious games for children with ASD and proposed an enhanced platform that will allow therapists to monitor and control the treatment of children with ASD more efficiently and effectively by providing them with useful information for their analysis and improvement of the treatment plan. The platform was also validated in the treatment of children with ASD who experience difficulties recognizing others' emotions and mental states.

This paper is organized as follows. It begins by analyzing some proposed models, architectures and existing serious game technologies. Then, it focuses on the description of the proposed platform. Finally, it culminates with the conclusions and the results obtained from the intervention.

\section{STATE OF THE TECHNOLOGY ART}

Previous studies have attempted to address ASD through the development of serious games. The devices and technological models that have been used in previous proposals will be briefly analyzed below.

\section{A. Recommended Hardware}

Table I shows the main devices found in the investigation. Analyzing this information, it can be identified that mobile devices, such as Smartphones and Tablets, are used more frequently due to their portability and ease of acquisition. 
TABLE I

MAIN TECHNOLOGICAL DEVICES

\begin{tabular}{|c|l|l|}
\hline $\mathrm{N}^{\circ}$ & \multicolumn{1}{|c|}{ Hardware } & \multicolumn{1}{|c|}{ Reference } \\
\hline \multirow{2}{*}{1} & IPad/Tablet/Smartphone & {$[8] ;[9] ;[10] ;$} \\
& & {$[11] ;[12] ;[13]$} \\
\hline \multirow{2}{*}{2} & \multirow{2}{*}{ Desktop PC } & {$[14] \quad[15] ;[16] ;$} \\
& & {$[17]$} \\
\hline 3 & Virtual Reality & {$[16] ;[17] ;$} \\
\hline
\end{tabular}

B. Serious Game Models and Technological Architectures

"Fill Me App" proposes a model for a mobile game application that helps people with ASD to identify the parts of the human body [13]. The technological architecture of this model suggests the use of an Android mobile device, as shown in Figure I.

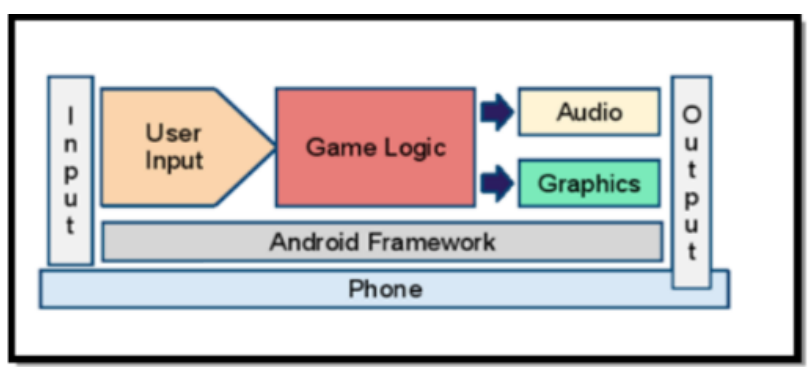

FIGURE I

“FILL ME APP” ARCHITECTURE FOR A MOBILE GAME FOR CHILDREN WITH ASD

In Figure II, the use case diagram of the "Fill Me App" application is shown, depending on the two users. It is important to note that the student must log-in to be able to play and the teacher evaluates the student's performance during the game.

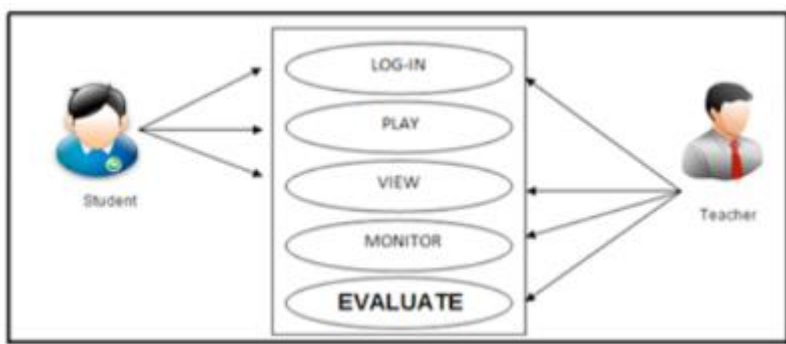

FIGURE II

"FILl Me APP" USE CASE DiAgRAM

Another model proposed for the treatment of people with ASD is based on facilitating technologies such as mobile devices, virtual reality systems and robots [16]. This model allows the analysis of information to generate feedback that improves the patient's conditions, as can be seen in Figure III.

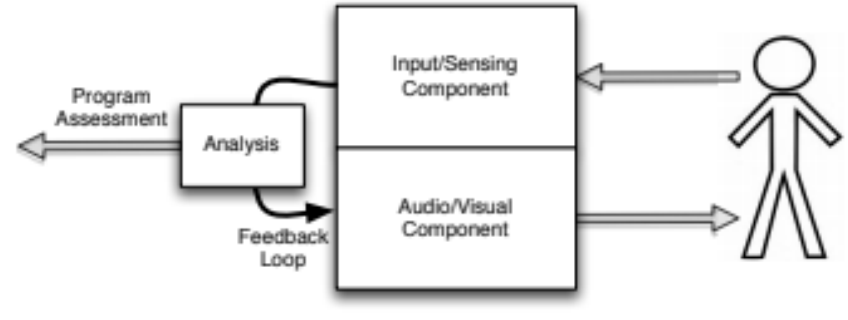

FIGURE III

MODEL OF SYSTEM FOR PEOPLE WITH AUTISM

One of the advantages of the mobile game model for children with autism is that it allows the teacher to monitor and evaluate the performance of students through a web application. However, in this model, the age of children with ASD is not contemplated. The age is essential, because the older children do not have the longest span of attention towards the game. Also, the first years of life are important to detect early abnormalities that can be treated [13].

On the other hand, the advantage of the second model is the use of technology-facilitated treatments, such as virtual reality, robots, mobile devices offering feedback that is analysed. Despite of this, there lacks a highly reliable and accurate sensing platform that can capture and recognize the emotional state of the participant [16].

\section{Cloud Platform Evaluation}

Cloud platforms have been used considerably in serious game applications due to their scalability and capacity to provide an infrastructure for the development and management of them; in addition to providing storage services, gamification, and analysis tools, among others [18]. Table II shows the cloud platforms utilized by the proposed serious game applications.

TABLE II

BENCHMARK ANALYSIS OF ClOUd PlatForms

\begin{tabular}{|c|c|}
\hline Platform & Description \\
\hline Microsoft Azure & $\begin{array}{l}\text { This platform can be easily associated with } \\
\text { AWS; since both give clients a complete set } \\
\text { of services. It helps reduce risk and } \\
\text { complexity through a hybrid cloud designed } \\
\text { to compile and implement solutions with real } \\
\text { coherence through all its technological pile } \\
\text { [19]. Thanks to our conditions as students of } \\
\text { Universidad Peruana de Ciencias Aplicadas } \\
\text { (UPC), we have access through our student } \\
\text { accounts to Azure for Students, which } \\
\text { provides us with } \$ 200.00 \text { in Azure credit to } \\
\text { use in the first } 12 \text { months, in addition to a } \\
\text { selection of free services without the need of } \\
\text { a credit card at the time of registration. }\end{array}$ \\
\hline $\begin{array}{l}\text { Google Cloud } \\
\text { Platform }\end{array}$ & $\begin{array}{l}\text { It is a platform that unites all web } \\
\text { development applications that Google used to }\end{array}$ \\
\hline
\end{tabular}

$17^{\text {th }}$ LACCEI International Multi-Conference for Engineering, Education, and Technology: "Industry, Innovation, And Infrastructure for Sustainable Cities and Communities”, 24-26 July 2019, Jamaica. 


\begin{tabular}{|c|c|}
\hline & $\begin{array}{l}\text { offer separately. It is used to create certain } \\
\text { types of solutions through the technology } \\
\text { stored in the cloud and allows, for example, } \\
\text { to highlight the speed and scalability of its } \\
\text { infrastructure in their search engine } \\
\text { applications. Google offers us a } 12 \text {-month } \\
\text { trial period. It also provides } 1 \text { GB of memory } \\
\text { and grants } \$ 300.00 \text { for development. [20] }\end{array}$ \\
\hline $\begin{array}{l}\text { Amazon Web } \\
\text { Services }\end{array}$ & $\begin{array}{l}\text { It is a cloud platform service that offers } \\
\text { powerful computing, database storage, } \\
\text { content delivery, and other functionalities to } \\
\text { help companies scale and grow. In addition, it } \\
\text { offers easy integration with other platforms } \\
\text { that offer cloud services, simplifying a hybrid } \\
\text { approach for companies. [21] }\end{array}$ \\
\hline $\begin{array}{l}\text { SAP Cloud } \\
\text { Platform }\end{array}$ & $\begin{array}{l}\text { SAP Cloud Platform is an open commercial } \\
\text { platform designed to innovate, integrate and } \\
\text { expand applications with agility and } \\
\text { flexibility. The multiple clouds that it has as a } \\
\text { base allow us to take advantage of the latest } \\
\text { native technologies of the cloud and obtain } \\
\text { benefits from the main scalable } \\
\text { infrastructures. It can be used as a platform to } \\
\text { create smart applications, which are ready for } \\
\text { mobile devices in order to better serve } \\
\text { customers, modernize business processes and } \\
\text { compete effectively. As the basis for a smart } \\
\text { company, SAP Cloud Platform allows } \\
\text { companies to react and grow rapidly to adapt } \\
\text { to new market expectations. [22] }\end{array}$ \\
\hline
\end{tabular}

After the evaluation, we opted for Microsoft Azure because of the following reasons. Microsoft Azure allows the ease of integration with other cloud platforms which make the application high in operability. Another reason is the University agreement that our institution has.

\section{PRoposed TECHNOLOGICAL PLATFORM}

After comparing the previous set of models and technological architectures for the use of serious games in the treatment of children with ASD and our informal discussions with local behavioral therapists, we found that there was a need to optimize the process of emotional and social learning therapies through a more enhanced platform. Some of the complaints for the current models include issues as: unfriendly interfaces, a lack of interoperability, involvement of the end users (children with ASD and therapists) in the design process, functionalities for therapists, visual information for decision-making and a lack of consideration of the children's age in the design process.
A. A comparative analysis of the proposed and current platforms.

In order to analyze the differences between the proposed platform and the other existing studies, a comparative evaluation is carried out. The key studied variables were: user participation (in the development process), sector, the age of the target audience, the technology used, the operating system on which the solution runs, the objective symptom it seeks to reduce and the frameworks on which they are based. Please refer to Table III for the comparison.

$17^{\text {th }}$ LACCEI International Multi-Conference for Engineering, Education, and Technology: "Industry, Innovation, And 
TABLE III

COMPARATIVE Evaluation OF EXISTING STUdIES

\begin{tabular}{|c|c|c|c|c|c|c|c|}
\hline & $\begin{array}{l}\text { PROPOSED } \\
\text { SOLUTION }\end{array}$ & MINDLIGHT & $\begin{array}{l}\text { VIRTUAL } \\
\text { PINK } \\
\text { DOLPHIN }\end{array}$ & $\begin{array}{l}\text { REACHOUT } \\
\text { ORB }\end{array}$ & $\begin{array}{l}\text { RICKY \& } \\
\text { THE SPIDER }\end{array}$ & SPARX & EMOTIPLAY \\
\hline $\begin{array}{l}\text { USER } \\
\text { PARTICIPATION }\end{array}$ & $\begin{array}{l}\text { INFORMANT, CO- } \\
\text { DESIGNER AND } \\
\text { TESTER }\end{array}$ & INFORMANT & INFORMANT & $\begin{array}{l}\text { INFORMANT } \\
\text { AND TESTER }\end{array}$ & INFORMANT & INFORMANT & INFORMANT \\
\hline AGE & 3-10 YEARS & 7-13 YEARS & - & 9-10 YEARS & 8-12 YEARS & $\begin{array}{l}12-19 \\
\text { YEARS }\end{array}$ & 4-10 YEARS \\
\hline TECHNOLOGY & $\begin{array}{l}\text { MOBILE } \\
\text { APPLICATION }\end{array}$ & VIRTUAL REALITY & $\begin{array}{l}\text { VIRTUAL } \\
\text { REALITY }\end{array}$ & $\begin{array}{l}\text { MOBILE AND } \\
\text { WEB }\end{array}$ & $\begin{array}{l}\text { MOBILE } \\
\text { APPLICATIO } \\
\mathrm{N}\end{array}$ & $\begin{array}{l}\text { MOBILE AND } \\
\text { WEB } \\
\text { APPLICATIO } \\
\text { N }\end{array}$ & $\begin{array}{l}\text { WEB } \\
\text { APPLICATIO } \\
\mathrm{N}\end{array}$ \\
\hline $\begin{array}{l}\text { OPERATING } \\
\text { SYSTEM }\end{array}$ & ANDROID & $\begin{array}{l}\text { WINDOWS AND OS } \\
\mathrm{X}\end{array}$ & $\begin{array}{l}\text { WINDOWS } \\
\text { AND Os X }\end{array}$ & $\begin{array}{l}\text { WINDOWS, } \\
\text { ANDROID } \\
\text { AND APPLE } \\
\text { SX }\end{array}$ & $\begin{array}{l}\text { WINDOWS } \\
\text { AND OS X }\end{array}$ & $\begin{array}{l}\text { WINDOWS, } \\
\text { OS X, IOS } \\
\text { AND } \\
\text { ANDROID }\end{array}$ & $\begin{array}{l}\text { WINDOWS } \\
\text { AND OS X }\end{array}$ \\
\hline $\begin{array}{l}\text { OBJECTIVE } \\
\text { SYMPTOM }\end{array}$ & $\begin{array}{l}\text { HIGH- } \\
\text { FUNCTIONING } \\
\text { ASD }\end{array}$ & ANXIETY & ASD & $\begin{array}{l}\text { ANXIETY, } \\
\text { DEPRESSION } \\
\text { AND STRESS }\end{array}$ & $\begin{array}{l}\text { OBSESSIVE } \\
\text { COMPULSIVE } \\
\text { DISORDER }\end{array}$ & DEPRESSION & $\begin{array}{l}\text { CONDITIONS } \\
\text { OF THE } \\
\text { AUTISM } \\
\text { SPECTRUM }\end{array}$ \\
\hline FRAMEWORKS & $\begin{array}{l}\text { PARTICIPATORY } \\
\text { DESIGN, } \\
\text { THERAPEUTIC } \\
\text { SERIOUS } \\
\text { GAMES, FOUR- } \\
\text { DIMENSIONA } \\
\text { L FRAMEWORK }\end{array}$ & $\begin{array}{l}\text { PARTICIPATORY } \\
\text { DESIGN }\end{array}$ & $\begin{array}{l}\text { THEORY OF } \\
\text { MIND }\end{array}$ & $\begin{array}{l}\text { PARTICIPATO } \\
\text { RY DESIGN }\end{array}$ & $\begin{array}{l}\text { PARTICIPAT } \\
\text { ORY DESIGN }\end{array}$ & $\begin{array}{l}\text { PARTICIPAT } \\
\text { ORY DESIGN, } \\
\text { SELF- } \\
\text { DETERMINAT } \\
\text { ION THEORY } \\
\text { (SDT) AND } \\
\text { EHEALTH } \\
\text { FRAMEWORK }\end{array}$ & $\begin{array}{l}\text { THEORY OF } \\
\text { MIND }\end{array}$ \\
\hline
\end{tabular}

As noted, the proposed platform takes into consideration the participation of the user as an informant, co-designer (in the case of the therapist) and tester (in the case of the children with ASD). In this way, it differs from the other proposals due to the involvement of the specialist and the users during the design and development phases of the application. Thus, it guarantees that the final product will be satisfactory for users.

On the other hand, the proposed platform differs due to the age range it covers (3 to 10 years), ages in which social and interpersonal skills are mostly developed. According to Guyer et al., both childhood and early adolescence mark periods of rapid brain growth. Regarding childhood, it has been proven that the brain reaches almost adult size at age 5; supporting fundamental processes such as the acquisition of language, attention, memory and self-regulation. Furthermore, regarding early adolescence, research has demonstrated that the brain changes in critical ways that allow the acquisition of more complex and controlled behavior, such as decision making, regulation of emotions and complex social experiences [23].

In addition, it uses mobile devices and the Android operating system, unlike the other proposals. This is because, during the investigation, several references were found that highlighted the use of mobile devices nowadays. This type of device has caused technology to be more accessible to people. Regarding the educational sector, many authors have proven that serious games have a positive effect on the development of children with ASD. This is because they enjoy video games and can get involved in virtual environments easily because they are predictable and soothing [6].

Finally, it should be noted that the proposal uses several frameworks as a base, such as the best practices described in "Therapeutic Serious Games", the concepts presented in "Theory of Mind" and the development activities of "Participatory Design", among others.

\section{B. Specific View}

The proposed platform contains the following components:

1) ASD Child: Child with ASD and patient receiving learning therapy.

2) ASD Therapist: Professional who facilitates the therapeutic sessions of children with ASD using the application.

$17^{\text {th }}$ LACCEI International Multi-Conference for Engineering, Education, and Technology: "Industry, Innovation, And Infrastructure for Sustainable Cities and Communities”, 24-26 July 2019, Jamaica. 
3) Interaction: It refers to the input of information by users (children with ASD and therapist).

4) Game: It refers to the game that was developed in order to improve the emotion recognition abilities in children with ASD.

5) Mobile Device: Mobile device with which end users interact with the serious game.

6) Wi-Fi: Medium through which the mobile device and the game can connect to the Internet, both tablets and smartphones can use this medium.

7) Mobile Data: Medium by which the mobile device can connect to the Internet. Only applies if a smartphone is used.

8) Data Server: Database server that is responsible for storing compiled data from the inputs of both types of user (children with ASD and therapist).

9) Processing: Processing of the stored data to convert it into useful information to be analyzed by the therapist.

10) Dashboards: They are a set of graphic visualizations presented through a user interface that organizes and presents information in a way that is easy to read and interpret [24].

11) Operating System: Software that manages all the resources of the mobile device. It is an essential component for the hardware to work in an optimal way and so that the application can be used correctly.

12) Game Engine: A game engine simplifies the task of programmers by offering convenient abstractions for the hardware and operating systems on which the game is run. The purpose of a game engine is to make the most of the capabilities of host machines so that the player can get the most immersive game experience possible [25].

13) Cloud: Cloud Computing refers to a set of IT services that are provided to a customer through a leased network, with the ability to expand or reduce their service requirements. In general, Cloud Computing services are delivered by an external provider that owns the infrastructure. Cloud Computing has the potential to eliminate the requirements for the installation of high-cost IT infrastructure for IT-based solutions and services used by the industry. It provides a flexible IT infrastructure, accessible via the Internet from portable devices [26].

14) Internet: It is an electronic communications network that connects computer networks around the world. It is required that the mobile device is connected to the Internet because there needs to be a constant update of the collected data obtained from the interaction of the users with the application.

15) Development Platform: This element refers to an Integrated Development Environment (IDE), which is a software application that provides comprehensive facilities to computer programmers for software development. Normally, an IDE consists of a source code editor, compilation automation tools and a debugger [27].

\section{Process View}

The following phases describe the proposed platform. 1 . Therapists register the patient's data through the application and children interact with the game modules, 2. Game data is transmitted via Wi-Fi or Mobile Data, 3. Game data is stored in the cloud server and dashboards are generated, 4. The information visualized in the dashboards is analyzed by the therapists through the mobile application. Figure IV shows a graphical representation of the proposed technological platform.

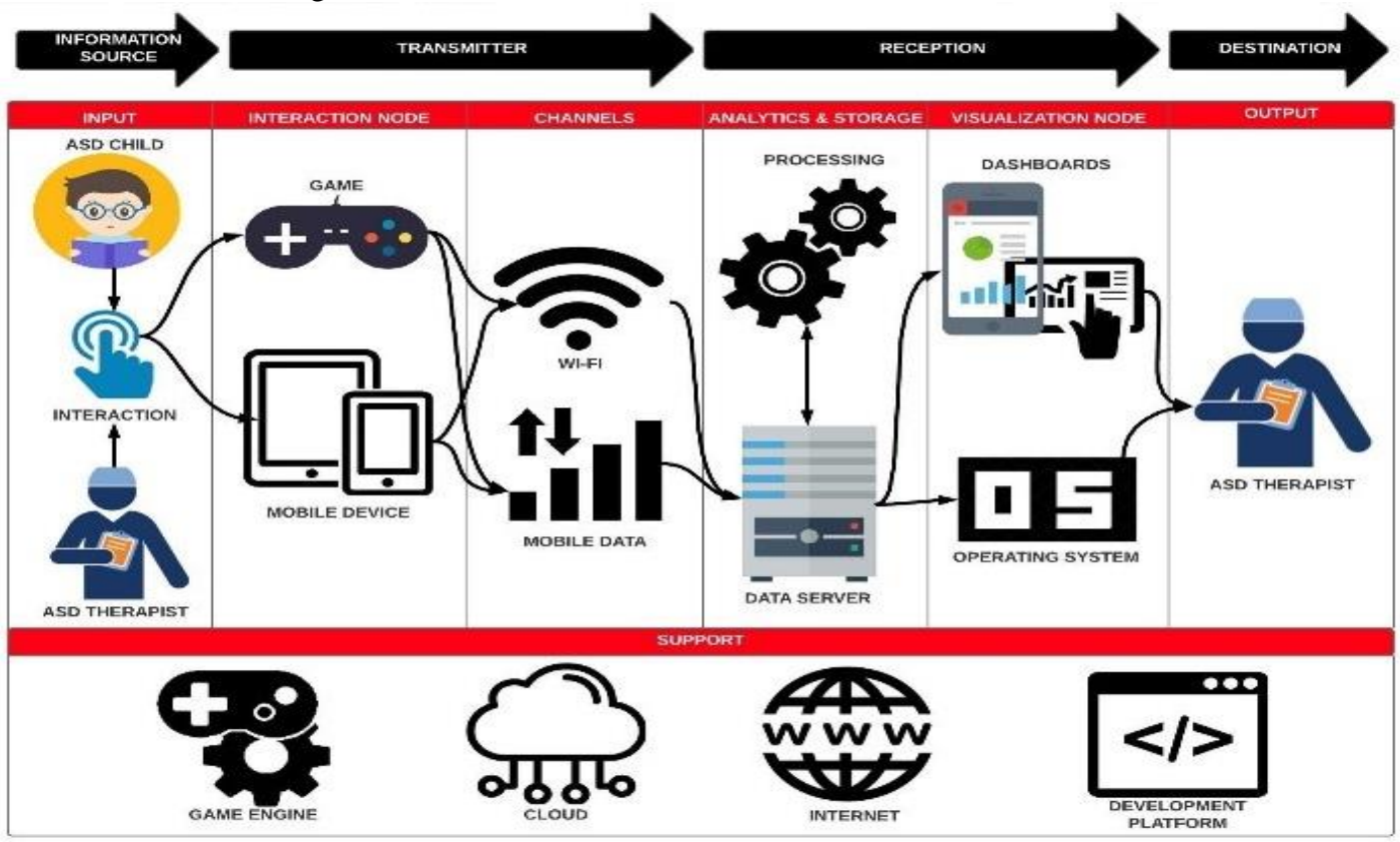

FIGURE IV

TeChNOLOGiCAL Platform to SUPPORT COGNITIVE AND BEHAVIORAL THERAPIES

$17^{\text {th }}$ LACCEI International Multi-Conference for Engineering, Education, and Technology: "Industry, Innovation, And Infrastructure for Sustainable Cities and Communities", 24-26 July 2019, Jamaica. 


\section{1) Input:}

The technological platform requires input information from the therapist who uses the application during therapy sessions. The therapist enters the child's initial diagnosis, as well as their personal data through the mobile device interface. In addition, children use this same application to interact with several game modules.

\section{2) Interaction Node:}

The technological platform works through mobile devices since it has been demonstrated that the use of technology in education facilitates learning in children with ASD, since "they feel more secure and comfortable exploring the virtual world and getting immediate feedback without feeling anxious about social rejection" [28]. Advances in mobile technology have allowed educators to send instruction messages in a flexible way [29]. For this reason, the technological platform has been designed based on this technology.

\section{3) Channels:}

Channels are the means through which information can be transferred. This component is fundamental because all the information compiled during the use of the application will be useful for the future processing and transformation of this. For this reason, mobile devices are connected to the Internet via Wi-Fi or Mobile Data.

\section{4) Analytics \& Storage:}

The proposed technological platform contains servers in which data can be stored and managed. The most fundamental data found is: user response, response time and children's feelings when using the application.

\section{5) Virtualization Node:}

The virtualization node of the technological platform allows the visualization of dashboards where the information is compiled and processed. Through this tool, therapists can observe the progress of each one of their patients and their interaction with each game module. This observation can be done in real-time if required. Examples of performance indicators could be the time spent in each module and the patient's feelings during the game.

\section{6) Output:}

The output consists of a series of quantitative and qualitative reports to facilitate and enhance the process of diagnoses and treatment. Reports can be tailored to the needs of each patient and aggregated results can also be collected and analyzed.
7) Support:

The technological platform is supported by components that ensure the continuity and optimization of computing resources needed to run the serious games. These components include: Game Engine, Development Platform, Internet and Cloud.

\section{E. Indicators View:}

An example of an indicator to measure the performance of the proposed technological platform is shown in Table IV. These times were preliminary results conducted at the office of an ASD specialist and her patients. Details of the pilot study and findings are discussed in the next section.

TABLE IV

INDICATORS

\begin{tabular}{|c|c|c|c|c|}
\hline & & \multicolumn{2}{|c|}{ Average Time (min.) } & \\
\hline $\begin{array}{c}\text { Age } \\
\text { Range }\end{array}$ & $\begin{array}{l}\text { \# of } \\
\text { Children }\end{array}$ & $\begin{array}{c}\text { Before the } \\
\text { proposed } \\
\text { platform }\end{array}$ & $\begin{array}{c}\text { After the } \\
\text { proposed } \\
\text { platform }\end{array}$ & $\begin{array}{c}\% \text { of } \\
\text { Improvement }\end{array}$ \\
\hline $3-5$ & 5 & 4.4 & 3.4 & $22.73 \%$ \\
\hline $5-8$ & 11 & 3.91 & 3.18 & $18.67 \%$ \\
\hline $8-11$ & 2 & 2.5 & 2.5 & $0 \%$ \\
\hline
\end{tabular}

\section{CASe STUdY}

\section{A. Organization}

An invitation to participate in the study was sent to three centers specialized in cognitive and behavioral therapy for ASD children. One therapist from a center in the district of Miraflores in Lima, Peru agreed in actively participating in the study. The therapist was eager to introduce a technological application to her practice and worked closely with the research team in the design of the platform. One of the therapist's challenges during her practice was the need of a tool that could allow her to optimize her time spent in designing personalized treatments for her patients (e.g., from diagnoses to progress assessments). The center provides treatment to children from the ages of 3 to 10 . The study involved 20 children with ASD and was conducted between October and December of 2018. The study received Ethics clearance by the University and the center. Because there was not a technological application previously in place, an analysis before and after use of the application was conducted.

\section{B. Experimentation}

1) Obtaining levels of emotional recognition through a mobile device:

An Android tablet that contained a mobile game application was provided to the therapist. This mobile game application was designed by the authors and the therapist, who assumed the role of co-designer. It was designed considering the therapist's needs and based on the proposed technological

$17^{\text {th }}$ LACCEI International Multi-Conference for Engineering, Education, and Technology: "Industry, Innovation, And 
platform, so it could be validated. The mobile game application contains 4 game modules:

1. Emotion Bubbles: Animated bubbles containing basic and mixed emotions appear on screen. The player must pop the bubbles that contain the solicited emotion (displayed in text or audio).

2. Logical Sequence: Two sequential images appear on screen for a few seconds. Then, the player is presented with three new images. The player must choose which image completes the sequence. When they choose the correct answer, the image becomes a puzzle they must solve.

3. Emotion Sudoku: A traditional game of sudoku, that uses caricaturized images of emotions instead of numbers.

4. Humpty Dumpty: A game that allows the therapist to play with her patients. It consists in a structure of bricks, with a character on the top. The players must take turns destroying the bricks. The player who makes the character fall, loses. During gameplay, the character changes their emotion and the patient must indicate how the character is feeling.

The therapist was trained to use the mobile game application correctly. Furthermore, the therapist was provided with two basic and mixed emotional recognition evaluations for her patients: one to be applied before the use of the mobile game application and another, after. This way, the therapist attended their patients involving the mobile game application and the evaluations at the start and end of each session.

\section{2) Data reception in mobile application:}

The mobile device sends all the results obtained to the mobile application, which is used to store data in the SQL Server 2016 database, hosted on Azure. It is extremely important that the mobile device has an Internet connection so that the mobile application can connect to this database through Wi-Fi or Mobile Data in real time.

\section{3) Information storage and data analysis:}

All the data stored in the database was used to evaluate the results of the children. For the pilot study, the therapist collected the time spent in recognizing basic and mixed emotions before and after using the mobile application and performance indicator based on the "Theory of Mind" (the ability to infer and understand what other people are thinking or feeling in any situation), that consisted of a measurement to detect the degree of empathy in children. Figure $\mathbf{V}$ shows a graphical representation of the information displayed in the dashboards.

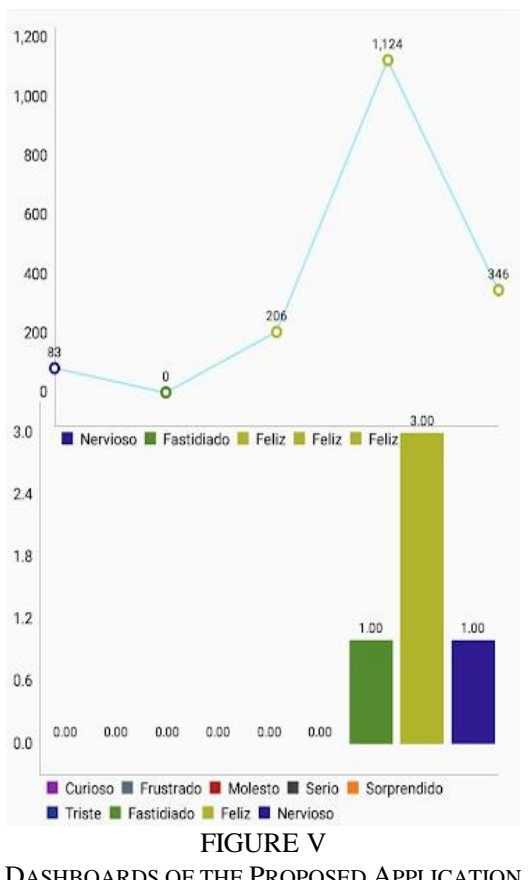

\section{Analysis of the Results:}

Based on the compiled data, it can be seen how correct management of the information is important for making decisions about the treatment of children with ASD. The mobile device and the data transfer facilitated the control and monitoring of the children during the therapeutic sessions. Likewise, the generated dashboards served as input for the therapist to arrive at a diagnosis and to develop customized treatment plans for her patients. The preliminary results show that $67 \%$ of the patients improved their skills of emotion recognition (represented in caricatured and human facial expressions) after two weeks of receiving this personalized treatment with the application. The results are shown in Figure VI.

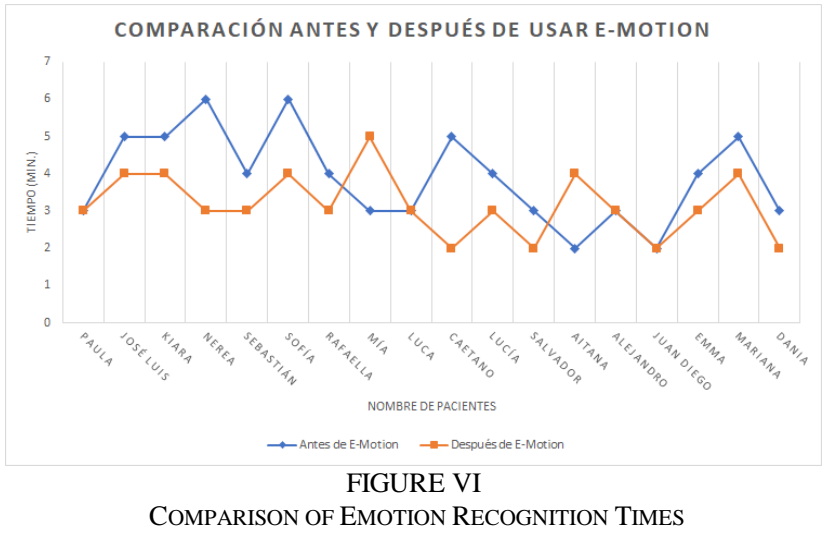

$17^{\text {th }}$ LACCEI International Multi-Conference for Engineering, Education, and Technology: "Industry, Innovation, And Infrastructure for Sustainable Cities and Communities", 24-26 July 2019, Jamaica. 
Furthermore, it was observed that the improvement was more significant in young children (ages 3 to 8 ) than older children (ages 8 to 10). These results are in accordance with evidence from V. Mohan, S. K. Kunnath, V. S. Philip, L. S. Mohan and N. Thampi [11] ; H.-C. Chu, W. W.-J. Tsai, M.-J. Liao y Y.-M. Chen [15]; and Wilkes-Gillan and Joosten [3]. The results mentioned were achieved in a period of 2 weeks of using the mobile game application in every therapy session with each child.

\section{CONCLUSIONS}

In this paper, a technological platform was proposed to improve the diagnoses and treatment of children with ASD. A major contribution of the proposed platform is twofold. First; we emphasized the Participatory Design framework in the design of the platform and application. The therapist was actively engaged and involved in all phases of the development. Second, because of this user-design participation, key performance indicators were developed to design specialized dashboards as a business intelligence tool for the therapist. The platform was tested in a center for cognitive and behavioral therapy for children with ASD in Lima, Peru. This application is among the few mobile tools developed and used in developing countries as well as Spanish speaking countries. The level of emotion recognition in children with ASD improved by almost $30 \%$ in two weeks of treatments after using the developed mobile game application. The therapist expressed satisfaction with the platform because it provided more visual information to be able to make correct and adequate decisions regarding the treatments to be followed. Before the use of this technological platform, therapies consisted of using mostly physical elements and a few mobile applications. The therapist also found the technology easy to use, due to the friendly interface, in comparison to other mobile games she has used in the past, which only consisted of basic learning games for children and did not provide information for decision-making in treatment plans. Therapists could propose personalized treatments for their patients according to the values obtained through the use of the mobile application; as such tailored strategies could be designed. In addition, several patients could be treated at the same time, running the mobile application on several mobile devices, which could lower the cost of therapies making them available to families with low income and making it possible for group therapy sessions to take place. Remote therapy sessions could also be a possibility with this solution. This paper reveals only preliminary findings.

For further research, authors must ensure that the sample of children who use and test the solution is extended to a more representative amount.
Finally, the therapist verified the great impact that a platform of this type could have on the business processes of several organizations dedicated to the treatment of children with ASD, as well as other similar disorders.

\section{REFERENCES}

[1] Organización Mundial de la Salud, «Organización Mundial de la Salud,» OMS, 04 Abril 2017. [En línea]. Available: http://www.who.int/es/news-room/fact-sheets/detail/autism-spectrumdisorders. [Último acceso: Diciembre 2018].

[2] INEI, «Características de las Personas con Discapacidad,» INEI, Lima, 2015.

[3] S. Wilkes-Gillan y A. Joosten, «Technology-based interventions were found to have evidence of effectiveness on a range of outcomes, including social problem solving and facial and emotional processing skills for individuals with autism spectrum disorders.,» Australian Occupational Therapy Journal, vol. 63, nº 2, pp. 135-136, 2016.

[4] Q. W. W. Z. a. X. L. X. Liu, «Technology-Facilitated Diagnosis and Treatment of Individuals with Autism Spectrum Disorder: An Engineering Perspective,» Applied Sciences, vol. 7, no 1051, pp. 1-31, 2017.

[5] C. B. a. A. P. E. Vallefuoco, «Serious Games in Autism Spectrum Disorder An Example of Personalised Design,» de Proceedings of the 9th International Conference on Computer Supported Education, 2017.

[6] O. G. S. S. A.-L. J. K. B. D. C. C. Grossard, «Serious games to teach social interactions and emotions to individuals with autism spectrum disorders (ASD),» Computers and Education, pp. 195-211, 2017.

[7] E. M. Whyte, J. M. Smyth y K. S. Scherf, «Designing Serious Game Interventions for Individuals with Autism,» Journal of Autism and Developmental Disorders , vol. 45, nº 12, pp. 1-12, 2014

[8] J. E. H. B. a. C. M. M. T. K. Boyd, «Evaluating iPad Technology for Enhancing Communication Skills of Children With Autism Spectrum Disorders,» Intervention in School and Clinic, pp. 1-9, 2015.

[9] K. H. L. a. B. P. S. K. B. Aspiranti, «iPads/tablets and students with autism: a meta-analysis of academic effects,» Assistive Technology, 2018.

[10] S. M.-R. A. M. D. E. C. D. M. M. H. D. a. R. H. T. Haydon, «Using Video Modeling and Mobile Technology to Teach Social Skills,» Hammill Institute on Disabilities, pp. 1-9, 2016.

[11] S. K. K. V. S. P. L. S. M. a. N. T. V. Mohan, «Capitalizing on technology for developing communication skills in autism spectrum disorder: a single case study,» Disability and Rehabilitation: Assistive Technology, 2017.

[12] S. O. K. H. a. A. S. S. Hedges, «Technology use as a support tool by secondary students with autism,» Autism, pp. 1-10, 2017.

[13] J. M. L. D. J. R. S. M. M. U. M.-u. a. D. D. M. S. M. S. Eder, «Fill Me App: An Interactive Mobile Game Application for Children with Autism,» International Journal of Interactive Mobile Technologies, pp. 59-63, 2016.

$17^{\text {th }}$ LACCEI International Multi-Conference for Engineering, Education, and Technology: "Industry, Innovation, And Infrastructure for Sustainable Cities and Communities", 24-26 July 2019, Jamaica. 
[14] W. M. M. R. A. M. R. L. a. M. O. S. RAMDOSS, «Computer-based interventions to improve social and emotional skills in individuals with autism spectrum disorders,» Developmental Neurorehabilitation,» Developmental Neurorehabilitation, pp. 119-135, 2012.

[15] W. W.-J. T. M.-J. L. a. Y.-M. C. H.-C. Chu, «Facial emotion recognition with transition detection for students with high-functioning autism in adaptive e-learning,» Soft Computing, 2017.

[16] Q. W. W. Z. a. X. L. X. Liu, «Technology-Facilitated Diagnosis and Treatment of Individuals with Autism Spectrum Disorder: An Engineering Perspective,» Applied Sciences, pp. 1-31, 2017.

[17] P. P. a. K. Goldschmidt, «Utilizing virtual reality and immersion video technology as a focused learning tool for children with autism spectrum disorder,» Journal of Pediatric Nursing, pp. 8-9, 2017.

[18] IBM, «IaaS PaaS SaaS - Modelos de servicio cloud,» IBM, [En línea]. Available: https://www.ibm.com/cloud-computing/bluemix/es. [Último acceso: 10 Octubre 2018 ].

[19] Microsoft Azure, «Microsoft Azure,» Microsoft, 2018. [En línea]. Available: https://azure.microsoft.com/es-es/overview/what-is-azure/. [Último acceso: 14 Octubre 2018].

[20] Google Cloud, «Google Cloud,» Google, [En línea]. Available: https://cloud.google.com/?hl=es. [Último acceso: 14 Octubre 2018 ].

[21] Amazon, «AWS,» Amazon, [En línea]. Available: https://aws.amazon.com/. [Último acceso: 14 Octubre 2018].

[22] SAP, «SAP Cloud Platform,» SAP, 2019. [En línea]. Available: https://cloudplatform.sap.com/index.html. [Último acceso: 6 Febrero 2019].

[23] A. E. P.-E. K. \&. C. E. A. Guyer, «Opportunities for Neurodevelopmental Plasticity From Infancy Through Early Adulthood,» Child Development, vol. 0, p. 11, 2018.

[24] T. P. F. P. S.-K. C. a. F. Y. W. P. Chowdhary, «Model-Driven Dashboards for Business Performance Reporting,» de 10th IEEE International Enterprise Distributed Object Computing Conference (EDOC'06), Hong Kong, 2006.

[25] G. S. a. A. K. F. Messaoudi, «Dissecting Games Engines: the Case of Unity3D,» de International Workshop on Network and Systems Support for Games (NetGames), Zagreb, 2016.

[26] M. Nazir, «Cloud Computing: Overview \& Current Research Challenges,» Journal of Computer Engineering, pp. 14-22, 2012.

[27] P. J. a. V. Prakash, «Survey on Web Based Interface,» International Journal of Advance Research in Computer Science and Management Studies, pp. 243-247, 2015.

[28] T. S. M. T. W. a. K. A. N. A. Ahmad Zaki, «Therapeutic serious game design guidelines for stimulating cognitive abilities of children with speech and language delay,» Journal of Information and Communication Technology, pp. 284-312, 2017.

$17^{\text {th }}$ LACCEI International Multi-Conference for Engineering, Education, and Technology: "Industry, Innovation, And Infrastructure for Sustainable Cities and Communities”, 24-26 July 2019, Jamaica. 